\title{
PEWARISAN NILAI-NILAI HISTORIS DAN KEARIFAN LOKAL MASYARAKAT KAMPUNG ADAT DALAM PEMBELAJARAN SEJARAH
}

\author{
Dede Wahyu Firdaus ${ }^{1}$ \\ Dosen STAI Miftahul Huda Al Azhar \\ Jl. Pesantren No.2, Langensari, Kujangsari, Kujangsari, Banjar \\ Kota Banjar, Jawa Barat 46324
}

\begin{abstract}
ABSTRAK
Pada masa sekarang ini pendidikan modern yang lebih mengarah pada rasionalitas seringkali mengabaikan ilmu dari pengetahuan-pengetahuan lokal yang kaya akan nilai-nilai budaya. Sehingga akan menjadi sebuah permasalahan jika kita tidak dapat mengenal jati diri bangsa kita sendiri. Bagaimana kita dapat memiliki sebuah identitas nasional jika tidak mengenal akar budaya leluhur kita. Rendahnya pengetahuan akan keberadaan komunitas adat merupakan sebuah hal yang perlu diperhatikan oleh berbagai pihak. Selain itu perlu adanya sebuah kebijakan baru yang tidak hanya melindungi komunitas adat tersebut, tetapi mengenalkan nilai-nilai ajaran luhur yang dimiliki oleh komunitas-komunitas adat di Indonesia terhadap kaum muda di Indonesia. Untuk itu, dalam mengatasi berbagai gejala seperti di atas, sebenarnya dapat dipahami bersama dengan pendekatan budaya, yaitu pendekatan melalui pewarisan nilai-nilai historis dan kearifan lokal. Metode yang digunakan dalam studi ini menggunakan pendekatan kualitatif dengan metode etnografi. Pewarisan nilai-nilai historis dan kearifan lokal masyarakat kampung adat Kuta dalam pembelajaran sejarah ini dilakukan melalui proses penerapan model pembelajaran kontekstual. Model pembelajaran yang bisa digunakan agar hasil belajar bisa optimal dalam rangka pewarisan nilai sejarah lokal adalah dengan menggunakan Contextual Teaching and Learning (CTL). Model Pembelajaran ini merupakan suatu sistem pengajaran yang menghasilkan makna dengan menghubungkan muatan akademis dan konteks dari kehidupan sehari-hari siswa.
\end{abstract}

\section{Kata Kunci: Pewarisan Nilai, Kearifan Lokal, Pembelajaran Sejarah}

\begin{abstract}
Today, modern education that leads to rationality often ignores the knowledge of local knowledge that is rich in cultural values. So it will be a problem if we can not recognize our own national identity. How can we have a national identity if we do not know the roots of our ancestral cultures. The low knowledge of the existence of indigenous communities is a matter of concern to the various parties. In addition, there is a need for a new policy that not only protects the indigenous community, but introduces the noble teachings of indigenous communities in Indonesia to young people in Indonesia. Therefore, in overcoming the various symptoms as above, it can be understood in conjunction with the cultural approach, namely the approach through the inheritance of historical values and local wisdom. The method used in this study used a qualitative approach with ethnographic methods. The inheritance of the historical values and the local wisdom of the indigenous villagers of Kuta in the study of history is done through the process of applying contextual learning model. Learning model that can be used for learning outcomes can be optimal in order to inherit the value of local history is to use Contextual Teaching and Learning (CTL). This learning model is a teaching system that generates meaning by linking the academic content and the context of the student's daily life.
\end{abstract}

Keywords: Inheritance Value, Local Wisdom, Learning History

\footnotetext{
${ }^{1}$ Penulis Koresponden

E-mail address: dwmachiavellian@gmail.com doi: http://dx.doi.org/10.25157/ja.v4i2.906
} 


\section{PENDAHULUAN}

Upaya Pewarisan budaya dan kearifan lokal merupakan salah satu bagian penting dalam menumbuhkan dan membangun jati diri. Budaya adalah suatu cara hidup yang berkembang dan dimiliki bersama oleh sebuah kelompok orang dan diwariskan dari generasi ke generasi. Setiap daerah memiliki budaya yang berbeda antara satu dengan yang lainnya. Hal tersebut disebabkan oleh kebutuhan hidup yang berbeda di setiap daerah. Budaya terus berkembang dari generasi ke generasi mengingat kebutuhan manusia yang semakin banyak dan terus berkembang pula dalam berbagai aspek kehidupan.

Kondisi tersebut diperkaya lagi dengan keberadaan sejumlah komunitas yang terdapat dalam kelompok suku bangsa tersebut, salah satunya yang dikenal dengan sebutan komunitas adat. Komunitas adat merupakan suatu kesatuan lokal yang menempati suatu wilayah tertentu dan berinteraksi secara terus-menerus sesuai sistem adat istiadat tertentu pula. Dari definisi tersebut kita dapat melihat bahwa komunitas adat merupakan sekelompok orang dengan pranatapranata sosial yang berdiri sendiri sesuai dengan nilai-nilai yang mereka anut. Komunitas adat lebih memilih untuk hidup dengan cara nenek moyang mereka dibandingkan terhegemoni oleh kebudayaan mayoritas. Perbedaan inilah yang menjadikan komunitas adat sebagai kaum minoritas yang dianggap "berbeda" dengan masyarakat kebanyakan yang bertindak sebagai mayoritas. Karena itu tidak berlebihan jika saya menyebutkan bahwa komunitas adat merupakan para penjaga warisan budaya.

Kebudayaan yang terus berkembang akhirnya mempengaruhi perubahan kebudayaan di setiap daerah. Perubahan kebudayaan yang terlihat sangat jelas ada di daerah perkotaan. Bahkan di berbagai daerah pun masyarakat sudah hidup dengan gaya modern sehingga cukup sulit menemukan kelompok masyarakat yang masih memelihara budaya leluhurnya. Kebanyakan nilai-nilai budaya leluhur telah ditinggalkan karena dianggap sudah tidak sesuai dengan perkembangan zaman.

Dewasa ini, persepsi mengenai komunitas adat adalah sebagai obyek wisata yang menarik karena merupakan hal yang unik. Mereka melihat komunitas adat bukan sebagai suatu masyarakat yang memiliki derajat yang sama dengan masyarakat kota umumnya, tetapi lebih melihat kelompok orang yang berada dalam kategori "primitif". Bahkan terkadang komunitas adat lebih sering dikaitkan dengan kegiatan yang berbau mistik oleh masyarakat. Karena pada proses penanaman nilai pada kalangan masyarakat adat lebih berbentuk lisan atau pamali yang diturunkan secara generasi ke generasi tanpa mengerti alasan di balik itu semua. Contohnya seperti adanya hutan-hutan larangan di setiap kampung adat. Dalam pemahaman mereka, hutan larangan merupakan sesuatu yang dikeramatkan sehingga mendapatkan penjagaan dan ritual-ritual khusus dalam pengelolaannya. Intinya perawatan seperti itu bukan berarti sepenuhnya percaya pada hal yang berbau mistis tapi pada hakekatnya manusia memang sudah sepantasnya menjaga kelestarian alam dalam upaya menjaga kestabilan ekosistem yang ada.

Namun dibeberapa daerah ternyata masih ditemukan kelompok masyarakat yang memegang teguh budaya leluhurnya. Bahkan budaya itu masih terpelihara sampai sekarang. Salah satu contohnya adalah kampung adat yang terletak di Desa Karangpaningal Kabupaten Ciamis. Kampung adat tersebut bernama Kampung Kuta.

Dalam masa pembangunan dewasa ini, salah satu fungsi pendidikan adalah mengembangkan kesadaran nasional sebagai daya mental dalam proses pembangunan nasional dan identitasnya. Struktur kepribadian nasional tersusun dari karakteristik perwatakan yang tumbuh dan melembaga dalam proses pengalaman sepanjang kehidupan bangsa. Dengan demikian kepribadian dan identitasnya bertumpu pada pengalaman kolektif, yaitu pada sejarahnya. Dalam konteks pembentukan identitas bangsa, maka pendidikan sejarah mempunyai fungsi yang fundamental (Kartodirdjo, 1989).

Hasan (1999) dalam tulisannya "Pendidikan Sejarah untuk Membangun Manusia Baru Indonesia" membuat perspektif baru dengan berpijak kepada pengalaman masa lalu untuk memahami apa yang terjadi pada masa sekarang. Pandangan tersebut sebenarnya menghendaki pendidikan sejarah sebagai pengetahuan yang diharapkan menjadi wahana pendidikan untuk mencapai "the glorious past" dalam arti agar generasi muda dapat menghargai hasil karya agung di masa lampau terutama untuk memupuk rasa bangga (dignity) sebagai bangsa. Pendidikan sejarah tidak saja menjadi 
wahana memahami keagungan masa lampau dan pengembangan kemampuan intelektual tetapi juga menjadi wahana dalam upaya memperbaiki kehidupan sosial, budaya, politik, dan ekonomi.

Dewasa ini masyarakat Indonesia, nampaknya memiliki kesadaran sejarah yang rendah. Rendahnya kesadaran sejarah ini dapat dilihat dari cara bagaimana mereka memandang masa lalunya. Masa lalu seringkali hanya diingat sebagai barang antik yang dianggap tidak ada gunanya. Oleh karenanya masa lalu hanya dianggap sebagai dongeng saja yang tidak ada relevansinya sama sekali dengan kehidupan nyata di hari ini. Masa lalu seringkali juga dengan mudah dilupakan begitu saja.

Apalagi mengaitkan masa lalu dengan masa kini dan masa datang, dipandang sebagai tindakan mengada-ada dan hanya membuang waktu. Padahal, menurut para ahli, sejarah adalah bagian terpenting bagi pembentukan sebuah peradaban. Melaluinya manusia diajak untuk sejenak mengembalikan ingatan dalam rangka menghadirkan nilai-nilai sebuah peristiwa yang melingkupinya. "Siapa yang menguasai sejarah, menguasai masa depan, yang menguasai masa kini menguasai sejarah", demikian kata George Orwel. Ungkapan ini menyadarkan kita semua betapa pentingnya peran sejarah dalam membangun peradaban bangsa ke depan. Hal itu senada dengan ungkapan dari Soekarno yang berkata "JAS MERAH" Jangan sekali-sekali melupakan sejarah.

Uraian tersebut menunjukkan pentingnya pewarisan nilai-nilai historis dan kearifan lokal masyarakat kampung adat Kuta dalam pembelajaran sejarah sebagai upaya untuk menumbuhkan kesadaran masyarakat Sunda akan nilai sejarah dan budayanya.

\section{METODE PENELITIAN}

Metode yang digunakan dalam studi tentang masyarakat kampung adat Kuta Desa Karangpaningal Kecamatan Tambaksari Kabupaten Ciamis ini menggunakan pendekatan kualitatif dengan metode etnografi. Bogdan dan Taylor (1993:30) menyatakan bahwa metode kualitatif akan menunjuk kepada prosedurprosedur riset yang menghasilkan data kualitatif, ungkapan atau catatan orang itu sendiri atau tingkah laku mereka yang terobservasi. Pendekatan ini mengarah kepada keadaankeadaan dan individu secara holistik (utuh) jadi pokok kajian, baik sebuah organisasi atau individu, tidak akan diredusir (disederhanakan) menjadi variabel yang telah ditata atau sebuah hipotesa yang telah direncanakan sebelumnya, akan tetapi akan dilihat sebagai bagian dari sesuatu yang utuh.

Nasution (2003:10) secara terperinci menjabarkan karakteristik penelitian kualitatif, di antaranya lebih mengutamakan:

"Perspektif emic, artinya lebih mementingkan pandangan responden, yakni bagaimana ia memandang dan menafsirkan dunia dari segi pendiriannya. Peneliti tidak memaksa pandangannya sendiri. Peneliti memasuki lapangan tanpa generalisasi, seakan-akan tidak mengetahui sedikitpun, sehingga mendapat perhatian penuh terhadap konsep-konsep yang dianut partisipan".

Studi pada masyarakat kampung adat Kuta Desa Karangpaningal Kecamatan Tambaksari Kabupaten Ciamis ini menggunakan pendekatan kualitatif dengan metode etnografi. Spradley (2007:3) menyatakan bahwa etnografi merupakan pekerjaan mendeskripsikan suatu kebudayaan. Tujuan utama aktivitas ini untuk memahami suatu pandangan hidup dari sudut pandang penduduk asli, hubungannya dengan kehidupan untuk mendapatkan pandangan mengenai dunianya. Inti dari etnografi adalah upaya untuk mepelajari makna-makna tindakan dari kejadian yang menimpa orang yang ingin kita pahami.

Etnografi menurut Spradley (2007:12) adalah suatu kebudayaan yang mempelajari kebudayaan lain. Etnografi merupakan suatu bangunan pengetahuan yang meliputi teknik penelitian, teori etnografi, dan berbagai macam deskripsi kebuadayaan. Penelitian etnografi mendeskripsikan tentang cara berfikir, cara hidup, cara berperilaku sebagai "social settings study" (Denzin, 2000: 457). Etnografi bermakna untuk membangun suatu pengertian yang sistematik mengenai kebudayaan manusia dan perspektif orang yang telah mempelajari kebudayaan itu. Beberapa sumbangan yang khas dan penting dari etnografi adalah menginformasikan teori-teori ikatan budaya, menemukan teori grounded, memahami masyarakat yang kompleks dan memahami perilaku manusia.

Penelitian etnografi fokus pada masyarakat, memilih informan yang diketahui memiliki pandangan yang luas dan mendalam 
terhadap aktivitas masyarakat yang diteliti. Menekankan pada makna bagaimana masyarakat make sense kehidupannya, pengalaman, dan struktur dunianya sendiri (Creswell, 1994: 145). Pengidentifikasian dan pemilihan informan yang tepat akan memperkuat akses sumber data yang relevan dengan pertanyaan penelitian.

\section{HASIL PENELITIAN DAN PEMBAHASAN}

Pewarisan nilai-nilai historis dan kearifan lokal mengarah pada satu tujuan yakni adanya upaya penanaman nilai dan norma yang bermuara pada kesadaran sejarah di kalangan peserta didik. Untuk mencapai hasil tersebut maka diperlukan kesinambungan antara pendidikan formal dan informal karena dalam kesehariannya siswa hidup dalam dua lembaga pendidikan tersebut, dalam hal ini pendidikan formal diidentikan dengan sekolah dan informal adalah masyarakat. Kesinambungan pendidikan formal dan informal terkait dengan proses internalisasi terjadi Karena posisi yang bisa saling melengkapi. Kelemahan yang ditemukan dalam proses pendidikan formal yakni waktu yang terbatas serta tuntutan materi pelajaran yang lain dan nilai (value) apa sesuai untuk siswa bisa ditutupi dalam pendidikan informal karena dalam pendidikan jalur informal prosesnya terjadi di keluarga dan masyarakat. Begitu pula sebaliknya, lembaga pendidikan formal bisa menjawab ekspektasi masyarakat yang tinggi terhadap masa depan anaknya kelak yakni dengan adanya perangkat kurikulum dengan tujuan serta rambu-rambu yang jelas.

Sisi lain dari kurangnya kesadaran sejarah didasarkan pada proses transformasi keilmuan yang disampaikan guru terhadap siswa pada khususnya dan masyarakat pada umumnya. Terkadang masalah tersebut timbul akibat guru kurang inovatif terhadap materi yang disampaikan sehingga proses pembelajaran terkesan monoton dan membosankan.

Pendidikan sejarah dalam rangka pewarisan nilai sejarah lokal pada dasarnya hanya dapat berjalan ketika terjadi kesinambungan antara materi dan realitas yang terjadi di lingkungan sekitar peserta didik. Dengan demikian, pendidikan kontekstual menjadi sebuah keharusan dalam upaya penanaman nilai sejarah lokal pada siswa. Untuk menunjang pelaksanaan pewarisan nilai-nilai historis dan kearifan lokal dengan pembelajaran sejarah dapat dilakukan dengan penerapan pembelajaran kontekstual.

Model pembelajaran yang bisa digunakan agar hasil belajar bisa optimal dalam rangka pewarisan nilai sejarah lokal adalah dengan menggunakan Contextual Teaching and Learning (CTL). Elaine B. Jonhson (2008:57) menjelaskan bahwa CTL merupakan suatu sistem pengajaran yang menghasilkan makna dengan menghubungkan muatan akademis dan konteks dari kehidupan sehari-hari siswa.

Model pembelajaran kontekstual merupakan konsep belajar yang membantu guru mengaitkan antara materi dan situasi dunia nyata siswa serta mendorong siswa membuat hubungan antara pengetahuan yang dimilikinya dan penerapannya dalam kehidupan sehari-hari (Nurhadi dkk, 2003: 4). Senada dengan hal tersebut, pembelajaran kontekstual adalah suatu proses pendidikan yang holistik dan bertujuan memotivasi siswa untuk memahami makna materi pelajaran yang dipelajarinya dengan mengkaitkan materi tersebut dengan konteks kehidupan mereka sehari-hari (konteks pribadi, sosial, dan kultural) sehingga siswa memiliki pengetahuan keterampilan yang secara fleksibel dapat diterapkan (ditransfer) dari satu permasalahan ke permasalahan lainnya.

Model pembelajaran kontekstual merupakan model pembelajaran yang membantu guru mengkaitkan antara materi yang diajarkan dan situasi dunia nyata siswa, mendorong siswa membuat hubungan antara pengetahuan yang dimilikinya dan penerapannya (implementasi) dalam kehidupan nyata mereka sebagai anggota keluarga dan masyarakat. Penerapan model pembelajaran kontekstual pada upaya pewarisan nilai-nilai historis dan kearifan lokal khususnya di Kampung Adat Kuta harus bisa dioptimalkan karena selain mempermudah dalam pewarisan nilai, model pembelajaran kontekstual juga merupakan model pembelajaran yang sekarang ini sedang berkembang dalam dunia pendidikan.

\section{PENUTUP}

Sejarah lokal merupakan salah satu cabang studi dari ilmu sejarah yang menempati posisi penting dalam perkembangan sejarah dan pendidikan sejarah. Sebagai sebuah sejarah yang terjadi dilokalitas tertentu yang didalamnya memiliki daya pengikat identitas yang khas. Salah satu dari tujuan pendidikan sejarah adalah sebagai media pelestarian budaya. 
Sejarah lokal dalam perkembangannya merupakan penyempurna dari unit sejarah nasional, dimana sejarah lokal memiliki ciri khas tersendiri dan memiliki potensi yang besar dalam mengembangkan nilai-nilai positif, seperti pewarisan nilai-nilai historis dan kearifan lokal.

Namun, jam mengajar sejarah yang terbatas, dengan materi yang padat, dan pelajaran sejarah yang masih di nomerduakan membuat pengajaran sejarah lokal tidak bisa maksimal. Untuk mengatasi hal tersebut guru berinisiatif dengan memberikan penugasan untuk mengidentifikasi sejarah lokal yang ada di kawasan sekitar sekolah. Proses pengindentifikasian sejarah lokal tersebut membuat siswa mengerti lebih jauh mengenai sejarah lokal. Sejarah lokal yang di identifikasi tersebut tidak terbatas pada benda-benda fisik peninggalan sejarah tetapi juga sejarah lokal yang berbentuk lisan atau folklore.

Dengan demikian, dapat dikatakan bahwa peran guru dalam upaya pewarisan nilai sejarah jalur formal adalah sebagai perantara antara kurikulum dan masyarakat. Pendidikan sejarah jalur formal (sekolah) juga memanfaatkan folklore yang ada dan berkembang di tahapan informal (masyarakat) sebagai materi belajar para siswa karena dalam kurikulum terdapat materi sejarah lokal. Dalam pembelajaran kontekstual kesimanbungan terjadi ketika materi yang diajarkan dan dibahas dalam kelas sesuai dengan apa yang ada di lingkungan siswa, sehingga pembelajaran sejarah dalam upaya pewarisan nilai-nilai historis dan kearifan lokal khususnya di masyarakat kampung adat kuta jadi lebih bermakna dan bermanfaat bagi siswa.

\section{DAFTAR PUSTAKA}

Bogdan, R.C. dan Taylor, S.J. 1993. Qualitative Research for Education an Introduction to Theory and Method. Boston: Allyn \& Bacon Inc.

Creswell, John W. 1994. Research Design : Qualitative and Quantitative Approach. California: Sage Publication.

Denzin, Norman dan Yvonna S. Lincoln. (ed.). 2000. Handbook of Qualitative Research, second edition. California: Sage Publication.

Hasan, Said Hamid. 2007. Pendidikan Sejarah Indonesia: Isu dalam Ide dan Pembelajaran. Bandung: Rizqi Press.
1999. "Pendidikan Sejarah untuk Membangun Manusia Baru Indonesia". Mimbar Pendidikan. Nomor 2/XVIII Tahun. 1999. Bandung: University Press IKIP Bandung.

Jonhson, Elaine B. 2008 Contextual Teaching and Learning. Bandung: MLC.

Kartodirdjo, Sartono. 1989. "Menggali Warisan Leluhur Untuk Memperkokoh Identitas Nasional Fungsi Pembelajaran Sejarah Dalam Pembangunan". Makalah. Surakarta: PPS UNS.

Nasution, S. 2003. Metode Penelitian Naturalistik Kualitatif. Bandung: Tarsito.

Nurhadi, dkk. 2004. Pembelajaran Kontekstual dan Penerapannya dalam KBK. Malang: UM Press.

Spradley, J.P. 2007. Metode Etnografi. (terjemah). Yogyakarta: Tiara Wacana. 
Jurnal Artefak:

History and Education, Vol.4 No.2 September 2017

Halaman | 134 